\title{
African-American Business Ownership: Strength In Numbers, But Where?
}

\author{
Donna K. Cooke, (E-mail: cooke@fau.edu), Florida Atlantic University
}

\begin{abstract}
Federal and state governments have seen fit to create enterprise and empowerment zones which benefit community redevelopment. Are these areas good for minority businesses? Data from Broward County, Florida show that African-American owned businesses tend to be in ethnic communities. They also tend to be in enterprise zones moreso than the other groups, and less likely than women-owned businesses to be in industry clusters. The findings, if replicated in other diverse urban communities, have implications for potential minority business owners. Future research should address whether the differences in location patterns are related to business success.
\end{abstract}

\section{INTRODUCTION}

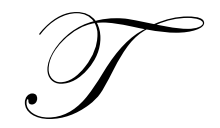

he persistently low rates of business ownership among minorities in the U.S. continue to attract attention from the private and public sectors. The interest is in part fueled by the belief that increased minority business ownership will ameliorate high rates of unemployment, poverty, and social ills. Despite recent gains, ethnic minorities remain underrepresented among business owners. Minorityowned businesses, owned by African Americans, Hispanics, Asians and Pacific Islanders, American Indians and Alaska Natives, make up 15 percent of businesses in the U.S. However, those minorities are more than 30 percent of the U.S. population (2000 U.S. Census). Of the largest minority groups, Hispanics are 17 percent of the population and own six percent of businesses, African-Americans are 15 percent and own four percent, and Asians are four percent and own over four percent of businesses (2000 U.S. Census).

Even though minority-owned firms grew four times faster than the national average from 1992 to 1997 (1997 Census), the statistics for African-Americans still lagged other minority groups on other indicators. AfricanAmericans tend to have smaller businesses and higher rates of business closure. Historically, the average sales and receipts for African-American businesses is about \$86,500 compared to \$155,200 for Hispanic-owned businesses (1997 U.S. Census). Based on data from the 1992 Characteristics of Business Owners, about 21 percent of AfricanAmerican business owners discontinued their failed businesses compared to 16 percent of the Hispanics and 15 percent of whites. This survey has since been discontinued so more recent comparable data are not available. In addition to the African-American transition rate into self-employment being a half that of whites, the AfricanAmerican transition rate out of self-employment is twice that of whites (Fairlie, 1999). These two realities are the immediate precursors to the under-representation phenomenon for African-American business ownership.

The process of deciding whether or not to form a business or to go into business is a complex one, fraught with many risks. Some of the first questions which need to be answered by the hopeful owner-to-be are, "What type of business should it be?" and "Where should that business be located?" The answers to these questions could play a determining role in the success or failure of the venture (Bruno \& Tyebjee, 1982). Not surprisingly, advice on how to answer these two questions abounds and often conflicts. There are pros and cons to locating a business in an established area as there are for a less established one. Likewise too for the type of business, there are arguments on both sides. Should the minority owner go into a business where there are already many others like him/her, or not? Of course, there are many other considerations beyond these. The purpose of this paper is to see how minorityowned businesses are represented in certain locations. To do this, I examine data from Broward County, Florida and 
test for patterns in the locations of businesses and in the types of businesses owned by minorities, with an emphasis on African-Americans. The paper is the first to address the question of location.

In the Minority Business Challenge report (Yago \& Pankratz, 2000) it states, "Economic growth cannot be sustained without the inclusion of minority businesses and an infusion of capital into those businesses." The report continues with, "America's economic future is so inextricably linked with minority and immigrant groups that investment in these communities is essential." Thus, the importance of minority businesses extends beyond minorities to other businesses and to the broader society. Consistent with the importance, both the private and the public sectors have taken an interest in improving the levels of minority business ownership.

With regard to the decision of where to locate, one approach that minorities could take is to be within an industry network or cluster. Businesses in a geographic area which are similar in terms of the resources used, production processes, or markets are identified as clusters (Heany \& Weiss, 1983). The logic is that when customers, suppliers and resources for an industry are "clustered" in one area, businesses in that industry will develop a competitive advantage. Using this logic, it would be beneficial to a new company to move into an already prospering cluster. By utilizing the resources in the network, the business owner has the potential to access labor, markets, and suppliers and perhaps enjoy some economies of scale in the process. For example, in the areas proximal to large college campus, one may find many businesses targeting students. If an entrepreneur would like to open a used book or CD store that surrounding area, it would be fairly easy to use the existing infrastructure to locate knowledgeable staff, potential customers, and sources of used books or CDs. The race of the business owners and of the residents in the cluster community is likely of little importance.

In the cluster approach, industry-related groups could provide instrumental business support. Over time they create a business environment which is very supportive of the type of businesses as resources and customers are drawn to the cluster. Some benefits of a cluster include lower marketing costs, easier access to a specialized workforce, and lower costs of transportation and the like. The concept of cluster is similar to that of incubators and has been advocated as a way to encourage minority entrepreneurs and their businesses (Yago \& Pankratz, 2000). The downsides to the cluster approach are increased competition within the cluster for customers and for resources which could lead to difficulties gaining market share and a higher cost of labor over time. The location of any one enterprise would not be a source of competitive advantage.

Given the already stated interests to society in minority-owned businesses, the public sector has reason intervene in order to stimulate enterprise in communities with heavy concentrations of minorities. There are many federal and state programs directed at encouraging minorities to go into business. These include various types of business assistance such as training and loans, and tax incentives and subsidies (cf. Austrian \& Norton, 2002). Of the programs, the ones especially relevant to the question of where to locate the business are enterprise communities and empowerment zones. These geographic communities are disadvantaged urban and rural areas so designated in order for the state or federal government to provide tax incentives and other business development stimuli. These incentives benefit the businesses located in these areas, and serve to attract new businesses. There is much emphasis on community redevelopment - safety, health care, housing, education, employment, in addition to the specific benefits to the businesses. The types of businesses which are drawn to these zones and communities (herein after referred to as zones) vary significantly, and they often share little in common other than their location. It should be noted that the ownership in these is not restricted to minorities as the primary purpose of the zones is to regenerate depressed communities and not necessarily to increase minority business ownership. In fact, only a small fraction of existing minority business owners have benefited from the programs that are in place (Schaefer, 1996; Zastrow and Kirst-Ashman, 2001).

Despite this, there are potential benefits for a minority owner to locate the business in a zone in which his/her race is already overrepresented. For one, the owner could derive social support from residents in the community since the residents have the ability to support political actions which affect the businesses. The residents could also provide instrumental support by being patronizing the business, or by giving positive public relations for the business. There is clearly the expectation too that the business will be supportive of the community. In fact, the enterprise zones often have tax incentives to encourage hiring with the area. The business can support the 
community by subsidizing community activities and other socially responsible actions. The disadvantages to locating in a zone can include poor infrastructure, higher crime, and other business hardships.

Where do minority business owners tend to locate, in an industry cluster or in a minority community? In this paper, I examine what minority business owners have done in Broward County, Florida. I present and test some hypotheses about where they are likely to be located. In future research, perhaps it will be possible to influence the phenomenon of African-American business ownership by encouraging entry into different types of enterprises and different locations, so I conclude this paper with suggestions for subsequent research.

For the purposes of this paper, the overlap between entrepreneurs and small business owners is sufficiently large that the terms are used interchangeably. The reason for overlooking the differences between entrepreneurs and small business owners is the central interest here in minority business ownership, regardless of who founded the business, or whether the business was purchased. The operational definition of minority business owner in use here is a self-identified minority who has at least a 50\% ownership stake in a business. I draw on both the entrepreneurship and small business literatures to inform this research on African-American small-business owners and business location. Surprisingly little has been written on this subject.

The decision to go into a business is based on personal and environmental factors. Miner (1996) found in his research that the majority of entrepreneurs have either marketing expertise, operations experience, or technical/product expertise. The entrepreneurs utilize their experience and expertise in their enterprise to good advantage. Butler (1991) theorized that African-American entrepreneurs emerge from difficult economic and social circumstances, and turn to enterprise as a means for achieving economic stability. They may go into businesses which are shunned by others, or enter professions such as medicine and law which can be operated as small businesses. For this middleman group, nurturing economic and community institutions are important. One could reason that such nurturing environments exist in their ethnic communities. Furthermore, depending on the type of business, the owners can enjoy advantages over outsiders with respect to marketing within the community. I believe that African-Americans are likely to be ethnic entrepreneurs, that is, they target members of their own ethnic community (see Chaganti and Greene, 2002 for a fuller discussion of ethnic entrepreneurs).

If African-American businesses are located in predominantly African-American or Caribbean areas and hire from the community as would be expected in enterprise zones, the zones constitute ethnic enclaves (Logan, Alba, \& Stults, 2003). There is little evidence that ethnic enclaves benefit businesses (Logan et al., 2003) and the location disadvantage would help to account for some of the poorer outcomes for those businesses. Thus, the first hypothesis:

H1: African-American owned businesses will be based in predominantly African-American and CaribbeanAmerican communities.

An extension of this hypothesis pertains to enterprise zones. I take the position that even though industry clusters may be more conducive to business success than are enterprise zones, minority owners may tend to locate in enterprise zones. If this is confirmed, it would help to explain the lower revenues and the higher levels of business failure among African-Americans. The purposes of an enterprise zone are multifaceted and are not necessarily targeted towards traditional metrics of business success such as growth, sales, and profits. The original intent of designating an area as an enterprise zone is community redevelopment. Business is but one aspect of that, and at times, adequate housing, health care, and employment may take precedence. In fact, the tax incentives and community pressure to increase employment may even lure owners to employ people they may neither want, nor need. Therefore, African-American businesses may face added challenges if they are located in enterprise zones.

Another reason I think the clusters are superior to enterprise zones is that they have a better business environment. The enterprise zones are by definition, blighted or underdeveloped areas. Crime may be high, customers lacking, and the neighborhood workforce may be a poor fit to the needs of the business. Years ago, Bates argued that as minority entrepreneurs became better educated and were able to secure more credit, they would go into businesses other than retail and personal services to heavy construction and manufacturing (1985). In the 
former businesses, one might expect some advantages to locating and hiring within the enclave. In the latter businesses, one would expect that the businesses would be better off in thriving industry clusters. I propose here, that that such diversification in the types of businesses has not occurred to a noticeable degree for AfricanAmericans. I expect to find African-American owned businesses in zones moreso than in clusters vis-à-vis other minority groups. Thus the second and third hypotheses:

H2: African-American owned businesses are more likely than non African-American owned businesses to be in enterprise zones.

H3: African-American owned businesses are less likely than minority or women-owned businesses to be in industry clusters.

\section{METHOD}

\section{Sample}

In order to have a sufficient sample of African-American owned businesses, an area with a large number of these businesses was selected. California, Texas, New York and Florida have the highest number of minorityowned businesses (1997 Economic Census). The data for this paper were from Florida, specifically, the database from Broward County's registry of women- and minority-owned businesses. This database was chosen because by its nature it would have a large number of African-American owned businesses, and they would be identified as such. I recognize that the range of businesses would be reduced since these are businesses which would bid on county contracts. Never-the-less, the types of businesses that do business with the county are very diverse.

The companies in the database mostly were located in Miami-Dade, Broward, and Palm Beach counties comprising the South Florida region. Broward County was selected as it is in an ethnically diverse area with large African-American and Afro-Caribbean sub-groups. Miami-Dade County was a viable alternative but it is largely Hispanic. Palm Beach County is the least ethnically diverse of the three. Only businesses listing their address as being in Broward County were used.

\section{Data}

The type of business forms the main heading in the database, so businesses are listed as being in Accounting, Advertising, and so on. These were later coded to conform to an industry code based on the SIC (1=agriculture and mining, $2=$ construction, $3=$ manufacturing, $4=$ transportation, $5=$ wholesale trade, $6=$ retail trade, $7=$ finance, insurance, and real estate, $8=$ services excluding automotive, and $9=$ automotive services). The database has the individual companies listed with additional information on address including ZIP code, whether the company is woman-owned, or minority-owned, the owner's race, the address of the business, and some keywords which sometimes specified the nature of the business. If a business is owned by a minority woman, it would be listed as a minority-owned business. Therefore, all businesses designated as woman-owned have a white owner. Since these are all categorical data, nonparametric statistics were employed to test the hypotheses.

\section{Results}

Of the 1602 registered minority contractors on the list, 650 were African-American, Hispanic, Asian, and women-owned businesses located within the county (see Table 1 for the breakdown). There are 246 AfricanAmerican owned, 132 Hispanic-owned, 232 woman-owned, and 40 Asian-owned.

Data from the most recent census in 2000 were used to identify cities and towns within Broward County with high concentrations of the minority groups relevant to this study. A city or town is defined as having a high concentration of a group if it had at least $25 \%$ more than the overall rate in the county. Twenty-five percent over the overall county rate was chosen as a more stringent standard for overrepresentation than simply exceeding the county baseline. For African-Americans the threshold is $25.6 \%$, since the population rate in the county was $20.5 \%$. Using this threshold there were seven cities or towns with high concentrations of African-Americans (Fort Lauderdale, 
Plantation, Lauderdale Lakes, Lauderhill, Miramar, North Lauderdale, and Pembroke Park). Of the 246 AfricanAmerican owned businesses, 137 were in these communities and 109 were not (see Table 1). Using the binomial test, 137 was significantly higher than the expected limit at the $\mathrm{p}<.05$ level (one-tailed). Thus the first hypothesis is confirmed. African-American owned businesses tended to be in areas with large African-American or AfroCaribbean representation.

In order to test Hypothesis 2 regarding enterprise zones, the city code was too general so street addresses had to be used. Four businesses in the sample did not have a street address and had to be dropped from this analysis. A variable was created with two values - in enterprise zone, and not in enterprise zone. The Chi-square statistic was used comparing African-American ownership with minority and women ownership, and the result supported Hypothesis $2(\mathrm{p}<.05)$ which posited that African-American businesses are more likely to be located in enterprise zones than other minority and women-owned businesses. Table 2 presents the breakdown of the data for minority and women owners. In this sample, the rate of African-American ownership in the zones doubled that of Hispanics and women. Interestingly, there were no Asian-owned businesses were in an enterprise zone (see Table 1).

For Hypothesis 3, it was necessary to first test for the existence of industry clusters. In the absence of an operational definition in the literature, I defined an industry cluster as one in which there was a statistically significant industry concentration within a city or town. The observed number had to exceed the expected number by $25 \%$. Again, the $25 \%$ mark was used to avoid spurious results. To exclude clusters which meet the statistical definition but are in fact trivial in size (e.g., 5 companies in a city is too small to be a cluster), I used 15 as a practical minimum for a cluster. Chi-square analysis was conducted for the industry and city variables to determine if there were indeed industry clusters. There were $(\mathrm{p}<.01)$. There was a construction cluster were in Deerfield Beach and a services cluster in Fort Lauderdale. Businesses in the appropriate SIC code in these areas were coded as being in the cluster; all others were coded as being out of the cluster.

To test the third hypothesis, I used Chi-square to compare the number of African-American owned businesses within and outside the two clusters with the other minority and woman-owned businesses within and outside the clusters. These data are reported in Table 2. There was no difference in cluster location between African-American owned businesses and those owned by other minorities or white women as a whole. A closer examination of the data for Hispanic, Asian, and women-owned businesses suggests that ethnic minorities tended not to be in clusters, but women were (Table 2). This was confirmed in a separate Chi-square test comparing women to the minority groups $(\mathrm{p}<.05)$. Thus Hypothesis 3 was only partially confirmed. All minority-owned businesses, not just the African-American owned were less likely to be in clusters than the women-owned businesses.

\section{DISCUSSION AND SUGGESTIONS FOR FUTURE RESEARCH}

This paper is the first to test for differences in where minority- and female-owned businesses are located. I found that African-American owned businesses tended to be located in African-American and Afro-Caribbean areas and in enterprise zones. Furthermore, African-American owned businesses tended not to be located near businesses in the same general industry, that is, industry clusters. In fact, the ethnic minorities in this sample tended not to be in clusters but women-owned businesses were (see Table 3 for a summary).

The findings in this present study are significant because of the implications they hold for explaining the underlying historical differences in the success rates of minority- and women-owned businesses. Could it be that the patterns in where minority owners locate their businesses influence indicators of business success? Any effect of business location on success of African-American owned businesses is yet to be determined but the results here do open up some avenues for further inquiry. In this study, there were similarities between African-American and the other ethnic groups here. All tended not to be in industry clusters, unlike the white, women-owned businesses which were most likely to be in the more conducive business environment of the clusters. The Asian-owned businesses are distinct from the ethnic-owned ones in the sample in that they are least likely to be in enterprise zones. AfricanAmerican owned businesses were the most likely to be in the challenging business environments of enterprise zones. It appears from these results of the current study that African-American businesses tend to be located in the most 
difficult business locations, followed by Hispanics, Asian, and then white women. Replications of this study could be conducted in other counties and states to see if the pattern of results holds. A robust pattern would signal important differences in business ownership and possible limitations to the success of minority-owned (especially, but not limited to African-American owned) businesses.

There are implications for the private and public sector interests in increasing minority business ownership. For example, banks may want to encourage minorities to locate businesses in clusters, when possible. Enterprise zones could do better in the long run to attract more established businesses, rather than struggling or fledgling businesses. Also, rather than developing diverse businesses in the zones, emphasis might be placed on building interrelated businesses to create more of a cluster environment.

Minorities who are potential business owners or investors should separate social interests from business interests when assessing the pros and cons of locations. Especially for a new business, the investment in time and resources may be greater in enterprise zones, so this reality must be factored in the decision of where to locate. Exceptions could be made for ethnic enterprises which market to ethnic communities. Locating in the target communities along with other similar enterprises could eventually lead to ethnic entrepreneurship, focused on ethnic markets. In the current study, one example of this is the community in Lauderhill has a significant AfricanAmerican and Caribbean presence. There was a statistically and practically significant overrepresentation of African-American businesses there as well. The community is well known locally as a thriving businesses area catering to the needs of these ethnic groups.

In any event, future research could compare similar minority-owned businesses in and outside of various types of ethnic communities to see if there are differences in measures of economic success. The most interesting contrasts would be between African-American and Hispanic-owned, and Asian and women-owned businesses. Further investigation to see under what conditions location matters in business success is warranted

\section{REFERENCES}

1. Austrian, Z, \& Norton, J. (2002). "Strategies and tools in economic development practice". Center for Economic Development, Maxine Goodman Levin College of Urban Affairs, Cleveland State University.

2. Bates, T. (1985). "Entrepreneur human capital endowments and minority business viability." The Journal of Human Resources, 20, (4), 540-554.

3. Bruno, A. V., \& Tyebjee, T. T. (1982). "The environment for entrepreneurship". In C. A. Kent, D. L. Sexton, \& K. H. Vesper (Eds.).” Encyclopedia of Entrepreneurship,” pp. 288-315. Englewood Cliffs, NJ: Prentice-Hall.

4. Butler, J. S. (1991). "Entrepreneurship and self-help among black Americans: A reconsideration of race and economics". SUNY Series in Ethnicity and Race in American Life.

5. Chaganti, R., \& Greene, P. (2002). "Who are ethnic entrepreneurs? A study of entrepreneurs' ethnic involvement and business characteristics." Journal of Small Business Management, 40, (2), 126-143.

6. Fairlie, R. W. 1999. "The absence of the African-American owned business: An analysis of the dynamics of self-employment." Journal of Labor Economics, 1, 80-108.

7. Heany, D. F., \& Weiss, G. (1983). "Integrating strategies for clusters of businesses." Journal of Business Strategy, 4, (1), 3-11.

8. Logan, J. R., Alba, R. D., \& Stults, B. J. (2003). "Enclaves and entrepreneurs: Assessing the payoff for immigrants and minorities." International Migration Review, 37, (2), 344-388.

9. Miner, J. B. 1996. The 4 routes to entrepreneurial success. Berrett-Koehler.

10. Schaefer, R.T. (1996). Racial and ethnic groups ( $5^{\text {th }}$ ed.) New York: Harper Collins.

11. 1992 US Census Characteristics of Business Owners http://www.census.gov/prod/3/97pubs/cbo-9201.pdf

12. 1997 US Census http://www.census.gov/epcd/www/ec97stat.htm

13. 1997 US Economic Census http://www.census.gov/epcd/www/econ97.html

14. 2000 US Census $2000 \mathrm{http} / / /$ factfinder.census.gov/servlet/BasicFactsServlet.

15. Yago, G., \& Pankratz, A. (2000). The Minority Business Challenge: Democratizing Capital for Emerging Domestic Markets. Milken Institute. 
16. Zastrow, C., \& Kirst-Ashman, K. (2001). Understanding human behavior and the social environment. $\left(5^{\text {th }}\right.$ ed).Belmont, CA Wadsworth.

Table 1 Businesses located in enterprise zone: African-American versus non African-American

\begin{tabular}{|c|c|c|c|c|c|}
\hline Minority status & $\mathrm{N}$ & In Enclave & Out of Enclave & $\begin{array}{l}\text { In } \\
\text { Enterprise Zone }\end{array}$ & $\begin{array}{l}\text { Out of } \\
\text { Enterprise Zone }\end{array}$ \\
\hline African-American & $246^{\mathrm{a}}$ & $137 *$ & 109 & $20 * *$ & 222 \\
\hline All Others & & 404 & & 15 & 389 \\
\hline Hispanic & & 132 & & 5 & 127 \\
\hline White women & & 232 & & 10 & 222 \\
\hline Asian & & 40 & & 0 & 40 \\
\hline
\end{tabular}

${ }^{\mathrm{a}}$ Four businesses had incomplete addresses and could not be classified as in or out of an enterprise zone.

$* \mathrm{p}<.05,1$-tailed; **p<.01, 1-tailed

Table 2: Industry clusters by minority status

$\begin{array}{rlll}\text { Minority status } & \text { In clusters } & \text { Out of clusters } & \text { p } \\ \text { African-American } & & 213 & \text { n.s. } \\ \text { Observed } & 33 & 208 & \\ \text { Expected } & 38 & 337 & \\ \text { All Others } & 67 & & .05 \\ \text { Hispanic } & & 115 & \\ \text { Observed } & 17 & 112 & \\ \text { Expected } & 20 & 186 & \\ \text { White women } & & 196 \\ \text { Observed } & 46 & & \\ \text { Expected } & 36 & 36 & \\ \text { Asian } & & 34 & \\ \text { Observed } & 4 & & \\ \text { Expected } & 6 & & \end{array}$

Table 3: Summary of hypotheses and results

\section{Hypothesis}

H1: African-American owned businesses will be predominantly in African-American and Caribbean-American communities

H2: African-American owned businesses are more likely than non African-American owned businesses to be in enterprise zones.

H3: African-American owned businesses are less likely than minority or women-owned businesses to be in industry clusters.

\section{Results}

Confirmed. Binomial test, $\mathrm{p}<.05$.

Confirmed. Chi-square test, $\mathrm{p}<.01$

Partially confirmed. Chi-square test, $\mathrm{p}<.05$. African-

American owned businesses were no less likely than other minorities to be in industry clusters. They did differ from women-owned businesses which tended to be in industry clusters. 
Notes 